\title{
Surface Analysis of Leached Simulated Waste Glass
}

\author{
S. S. Kim ${ }^{1,2}$, G. H. Lee', J. -G. Lee', K. Y. Jee' and K. S. Chun' \\ ${ }^{\prime}$ Korea Atomic Energy Research Institute(KAERI), P.O. Box 105, Yusong, Taejon, \\ ${ }^{2}$ Dept. of Chemistry, Chung Nam University, Taejon, Korea
}

\begin{abstract}
Leaching experiments on a simulated borosilicate waste glass were performed using a static method in the presence of $\mathrm{PbO}$ and bentonite. Ions in leachates were analyzed by ICP, while leached samples were characterized by several surface analytical methods such as XPS, SEM, EPMA, XRD and topography. As the simulated waste glass was leached in the presence of $\mathrm{PbO}$ and bentonite, lead hydroxide and insoluble elements $(\mathrm{Ti}, \mathrm{Nd}, \mathrm{Ru}$ and $\mathrm{Zr}$ ) were detected on the surface, respectively. On the other hand, a large amount of uranyl hydroxide was found on the surface of it when the borosilicate glass with $25 \% \mathrm{U}_{3} \mathrm{O}_{8}$ was leached in a soxhlet apparatus.
\end{abstract}

Keywords simulated borosilicate waste glass, leach, surface analysis

Borosilicate glass has been assessed as one of the best matrix materials for the immobilization of highlevel nuclear wastes. In order to isolate the radioactive waste safely from the biosphere for more than several thousands years, many environmental factors such as ground water, filler, metal barrier, buffer material, backfill material and rock should be considered in the leaching process of a borosilicate waste glass.

It has been known that leaching of waste glass increases in the presence of iron or sensitized stainless steel. ${ }^{1}$ However, when a small amount of $\mathrm{PbO}$ is added, leaching of waste glass can be greatly suppressed, with the formation of closed metal-glass interface, that blocks water penetration. ${ }^{2,3}$

Bentonite as a buffer material can increase glass corrosion remarkably due to the persistent removal of silicate ions from the leachant. ${ }^{4}$ Sorption or dissolution with reprecipitation of a silica-rich clay have been proposed as possible mechanisms for the silica consumption. However, Godon reported that the corrosion of radioactive R7T7 glass doped with Np237 and $\mathrm{Pu}-239$ can be limited by supplying silicate to the solution for the bentonite.

Perhaps the most fundamental level on which to approach glass corrosion is that of atomic-level structure. In this approach, many of the surface analysis techniques are used for the characterization of the glass before and after leaching. ${ }^{6}$
This paper presents the characteristics of the surface of simulated borosilicate waste glasses, which were leached in the static method with $\mathrm{PbO}$ and bentonite additive and the soxhlet method.

\section{Experimental}

\section{The preparation of simulated waste glass}

Three kinds of simulated waste glasses (X-, Y-, Zglass) were prepared by the process shown in Fig. 1. Powdered and disc samples were ultrasonically cleaned for 15 minutes using three organic solvents such as petroleum ether, isopropanol and acetone, respectively. ${ }^{7}$

In order to compare the leaching properties of prepared waste glasses, commercial borosilicate glass (C-glass) was cut, cleaned and annealed in the same procedure as that of waste glass. Table 1 lists the composition of starting materials for the waste glasses and $\mathbf{C}$-glass.

\section{Characterization}

Elemental analysis of the leachate was carried out with inductively coupled plasma emission spectrometry (ICP; Jobin Yvon, JP-50P).

Perfluoralkoxy(PFA) Teflon bottles were used for 


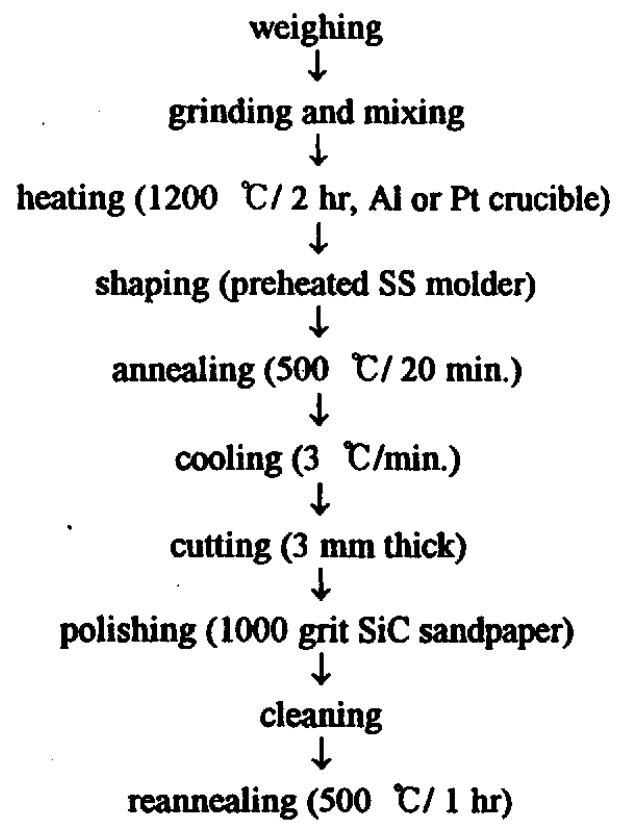

Fig. 1 Process of production of waste glass.

leach experiments after cleaning with diluted $\mathrm{NaOH}$ and $\mathrm{HNO}_{3}$ solutions based on the Ebert's method. ${ }^{8}$

Lead species adsorbed on the Y-glass discs were examined by $\mathrm{x}$-ray photoelectron spectroscopy (XPS; VG, ESCALAB 220i). Electron beam was injected to the sample in order to compensate a build-up of positive charge. Binding energy of lead deposited on the surface of Y-glass was calculated using gold (84.0 eV) dotted in the center of disc sample. The surface of $P t$ crucible contaminated in the process of preparing the $X$-glass was analyzed by secondary ion mass spectrometry (SIMS; VG, ESCALAB 220i). Powder $x$-ray diffractometry (XRD; Siemens, D5000) was employed to identify the phases of all products. Scanning electron microscopy (SEM) images and the composition analysis of the microscopic region area were acquired by electron probe microanalysis (EPMA; JEOL 860). Topology of leached sample was measured by microfocus measurement system (UBM Co., Germany).

\section{Leach test}

$0.1 \mathrm{~g}$ of Y-glass powder was added to the $15 \mathrm{ml}$ deionized water(DW) with or without $0.1 \mathrm{~g}$ of $\mathrm{PbO}$. The solutions were statically kept at $72{ }^{\circ} \mathrm{C}$ for 25 days. The leachates were filtered with $450 \mathrm{~nm}$ filter and analyzed by ICP. To clarify the inhibition of glass leaching in the presence of $\mathrm{PbO}, 0.1 \mathrm{~g}$ of $\mathrm{PbO}$ powder was added into deep and narrow bottle containing $5 \mathrm{ml}$ DW and a disc sample was placed against the wall of
Table 1 Composition of simulated waste and normal borosilicate glasses (wt \%).

\begin{tabular}{ccccc}
\hline & X-glass & Y-glass & Z-glass & C-glass \\
\hline $\mathrm{SiO}_{2}$ & 41.0 & 45.8 & 30.0 & 76.5 \\
$\mathrm{~B}_{2} \mathrm{O}_{3}$ & 11.1 & 15.3 & 10.1 & 13.8 \\
$\mathrm{Na}_{2} \mathrm{O}$ & 33.4 & 10.2 & 16.5 & 1.8 \\
$\mathrm{CaO}$ & 2.3 & 3.1 & 1.3 & \\
$\mathrm{Al}_{2} \mathrm{O}_{3}$ & 1.1 & 2.9 & 10.5 & 5.1 \\
$\mathrm{BaO}$ & & 0.5 & 0.1 & 1.4 \\
$\mathrm{~K}_{2} \mathrm{O}$ & & & 0.2 & 1.8 \\
$\mathrm{TiO}_{2}$ & 3.4 & 3.1 & 0.1 & \\
$\mathrm{Fe}_{2} \mathrm{O}_{3}$ & & 2.0 & 2.5 & \\
$\mathrm{Li}_{2} \mathrm{O}$ & & 1.0 & 0.4 & \\
$\mathrm{RuO}_{2}$ & 2.1 & 1.0 & 0.1 & \\
$\mathrm{MOO}_{3}$ & 2.1 & 2.0 & 0.2 & \\
$\mathrm{Cr}_{2} \mathrm{O}_{3}$ & 3.5 & 0.5 & & \\
$\mathrm{Nd}_{2} \mathrm{O}_{3}$ & & 5.1 & 0.2 & \\
$\mathrm{ZnO}$ & & 2.6 & 0.1 & \\
$\mathrm{ZrO}_{2}$ & & 1.8 & 0.2 & \\
$\mathrm{La}_{2} \mathrm{O}_{3}$ & & 1.0 & 0.1 & \\
$\mathrm{SmO}$ & & 0.3 & & \\
$\mathrm{Ce}_{2} \mathrm{O}_{3}$ & & 0.8 & 0.1 & \\
$\mathrm{NiO}$ & & 1.0 & & \\
$\mathrm{CoO}$ & & & 0.1 & \\
$\mathrm{U}_{3} \mathrm{O}_{8}$ & & & 27.2 & \\
\hline
\end{tabular}

the bottle. The glass discs were kept at $72^{\circ} \mathrm{C}$ for 25 days. The surface of the glass discs was analyzed by XPS after washing and drying.

$\mathrm{A} \mathrm{Y}$-glass disc and $0.5 \mathrm{~g}$ of bentonite were added to the $15 \mathrm{ml}$ ground water. The solutions were kept at $72^{\circ} \mathrm{C}$ for 36 days in the closed bottles filled with nitrogen gas. The surface of the discs was cleaned ultrasonically in methanol prior to surface analysis.

$\mathrm{C}$-glass and Z-glass discs were leached in dynamic system using a soxhlet apparatus for 48 hours. Samples were held with stainless steel wire.

\section{Results and Discussion}

The preparation of $S W$-glass

After preparing the $\mathrm{X}$-glass in $\mathrm{Pt}$ crucible, the surface of Pt crucible was analyzed by SIMS. The SIMS analysis of the surface of Pt crucible showed the contamination by a substantial amount of $R u$ on the Pt crucible, which indicated the diffusion of $R u$ into the Pt crucible. Measurements of XRD of the prepared Y-glass showed peaks of $\mathrm{RuO}_{2}$, too. This is 


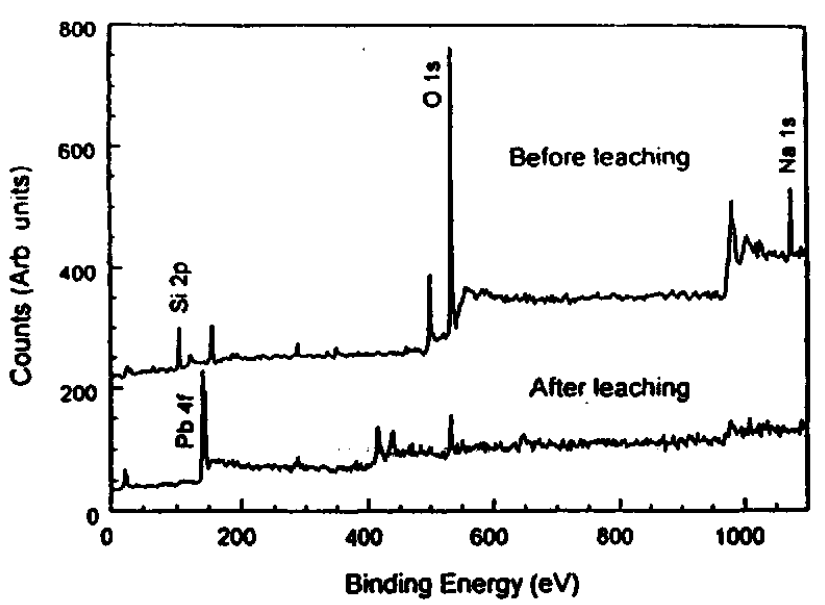

Fig. 2 Comparison of the XPS spectra for Y-glass surface before and after leaching experiment. Leach test was conducted in the solution with $\mathrm{PbO}$ powder.

consistent with the fact that platinum group compound is not vitrified with glass frits.'

\section{The addition of $\mathrm{PbO}$}

Compared to the concentrations of $\mathrm{B}, \mathrm{Na}$ and $\mathrm{Si}$ $(15.8,21.8$ and $45.6 \mathrm{ppm}$, respectively) in the leachate without $\mathrm{PbO}$, the concentrations in the leachate with $\mathrm{PbO}$ were very low, $0.38,1.82$ and $0.07 \mathrm{ppm}$, respectively.

XPS result of Y-glass disc indicated the appearance of strong lead peaks, after leaching in $\mathrm{DW}$ with $\mathrm{PbO}$ additive(Fig. 2). Binding energy of lead was calculated to be $138.06 \mathrm{eV}$, which is responsible for lead hydroxide. ${ }^{10}$ White lead hydroxide was also discovered on the surface of leached $\mathrm{C}$-glass in DW with $\mathrm{PbO}$ additive. Thus, the layer of lead hydroxide deposited on the surface of glass seems to inhibit the glass leaching.

\section{The addition of bentonite}

The microstructural change on the surface of Yglass disc after leaching experiment in the presence of bentonite was examined by SEM and EPMA. The smooth surface of Y-glass was changed to the fractured surface just like the surface of ground after a long period of drought. White stripes were also observed after leaching in SEM image (Fig. 3). EPMA results indicated that the area of white stripes contained more insoluble elements such as $\mathrm{Ca}, \mathrm{Ti}, \mathrm{Zr}$, $\mathrm{Ru}$ and $\mathrm{Nd}$ than the dark area. A large amount of insoluble elements observed on the surface of the leached Y-glass was also detected by XPS (Fig. 4).

The microfocus measurement showed that the white area was corroded more by about $2.2 \mu \mathrm{m}$ than the dark area.

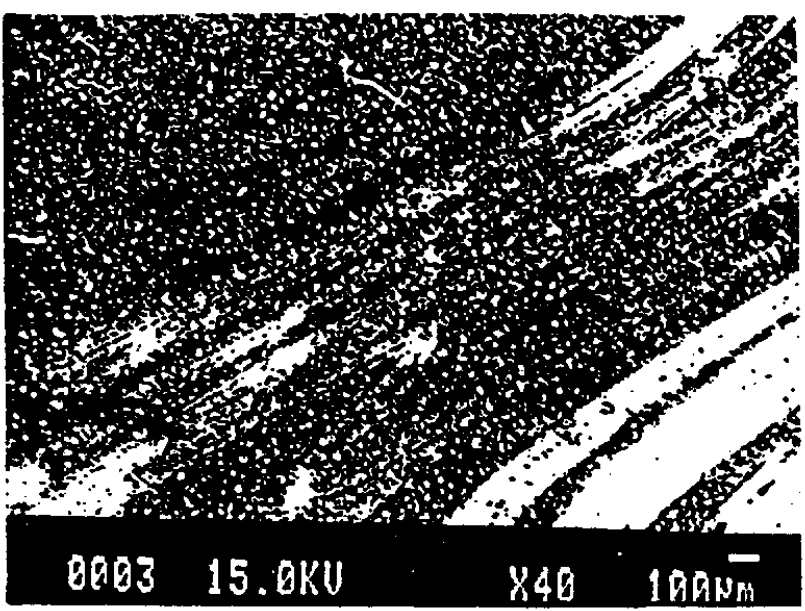

Fig. 3 SEM image of Y-glass surface after leaching for 36 days in the ground water with bentonite additive.

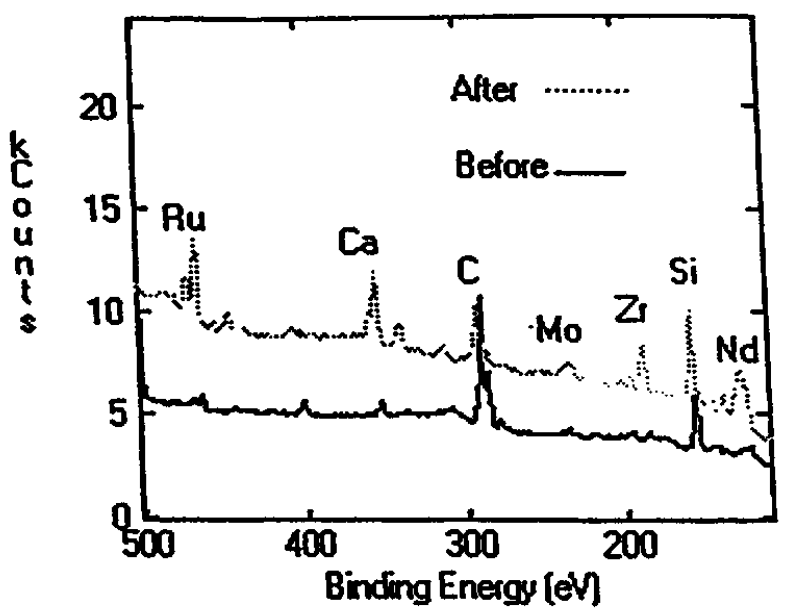

Fig. 4 Comparison of the XPS spectra of Y-glass surface before and after leaching experiment. Leach test was conducted in bentonite solution.

\section{The leaching of Z-glass}

It has been known that uranium occurs both in tetravalent and hexavalent forms in glass, but the hexavalent form is more stable." When the Z-glass was leached, the surface of it changed yellow. A large amount of uranium, which was identified as uranyl hydroxide by XRD, was detected in the yellow region by EPMA measurement.

\section{Conclusion}

The surface change of leached borosilicate waste glasses was analyzed by SEM, XPS and EPMA. The lead hydroxide and insoluble elements $(\mathrm{Zr}, \mathrm{Ca}, \mathrm{Ru}$, Nd) were detected from the surface of glass, as a simulated waste glass was leached in the solutions containing $\mathrm{PbO}$ and bentonite, respectively. The 
uranium was remained on the surface of waste glass after leaching experiment.

\section{References}

1. J. K. Bates, T. J. Gerding and A. B. Woodland, Mat. Res. Soc. Proc. , 176, 347-354 (1990).

2. G. Bart, H. U. Zwicky and E. T. Aerne, Scientific Basis for Nuclear Waste Management, 84, 459 (1987).

3. N. E. Bibler and C. M. Jantzen, Mat. Res. Soc. Symp. Proc., 84, 47 (1987).

4. N. Goden and E. Y. Vernaz, "Enhancement of the Glass Corrosion in the Presence of Clay Minerals: Testing Experimental Results with an Integrated Glass Dissolution Model", CONF921131130, 1992.

5. N. Godon et. al., "Radioactive SON 681817 LIC2A2Z1 Glass Interaction with Environmental Materials. Investigation of Irradiation Damage in Glass Specimens by Thermoluminescence", EUR-13613, 1992.

6. D. E. Clark and B. K. Zoitos, in "Corrosion of Glass, Ceramics and Ceramic Superconductors", pp. 78 - 91, Noyes Publications, New Jersey, U.S.A., 1992.

7. K. B. Harvey, C. D. Litke and C. A. B. Larocqe, Phys. Chem. Glasses, 33(2), 43 (1992).

8. W. L. Ebert, J. K. Bates and E. C. Bucks, Mat. Res. Soc. Symp. Proc., 294, 137 (1993).

9. Lars Carlsen and Pia Lassen, Waste Management, 12, 1 (1992).

10. L. R. Pederson, Journal of Electron Spectroscopy And Related Phenomena, 28, 203 (1982).

11. M. B. Volf, "Chemical Approach to Glass, Glass Science and Technology 7', Elsevier, New York, 1984. 